\title{
INFECTIOUS BRONCHITIS VIRUS IN CAPTURED FREE-LIVING, FREE-RANGE AND INTENSIVELY REARED BIRDS IN SOUTHWEST NIGERIA
}

\author{
Adebiyi, A. I. ${ }^{1}$, Fagbohun, A. F. ${ }^{2}$ \\ ${ }^{1}$ Department of Veterinary Microbiology and Parasitology, University of Ibadan, Ibadan \\ ${ }^{2}$ Federal College of Animal Health and Production Technology, Moor Plantation, Ibadan \\ Nigeria \\ adebiyiade@gmail.com
}

\section{ABSTRACT}

Infectious bronchitis (IB) is an acute infectious viral disease causing severe economic losses in poultry production. In Nigeria, there has only been monitoring of the disease in chickens with little attention given to other bird species. For this study, blood samples were collected from 184 apparently healthy, unvaccinated birds which comprised of 61 captured free-living pigeons, 60 free range indigenous chickens and 63 intensively reared Japanese quails. Sera from these birds were screened for IB virus antibodies (IBV) using a commercial ELISA kit. The birds were from Oyo and Osun States, in southwest Nigeria. Overall, 63 (34.2\%) sera were positive for IBV with $3.3 \%(2 / 61), 95.0 \%$ $(57 / 60)$ and $6.3 \%(4 / 63)$ from pigeons, indigenous chickens and Japanese quails, respectively. These findings suggest that they were subclinically infected with either field or vaccine virus and could thus serve as possible reservoirs of this virus to domestic poultry. Thus, there is need for continuous surveillance of the disease in different bird species and their possible role in the spread of IBV in Nigeria.

Key words: antibodies; indigenous chickens; infectious bronchitis virus; pigeons; quails

\section{INTRODUCTION}

Infectious bronchitis (IB) disease is distributed worldwide. It is an important highly contagious upper-respiratory tract viral disease of avian of all ages and is considered one of the main causes of economic losses in poultry production [5], causing: reduced weight gain, poor feed conversion efficiency, and high condemnation rates in meat-type birds [7]. The causative agent, infectious bronchitis virus (IBV), is a coronavirus which belongs to the family Coronaviridae and subfamily Coronavirinae within the genus of Gammacoronavirus [16]. This enveloped, positive-strand RNA virus has been reported not only to cause respiratory diseases but has been isolated from kidneys, different parts of the oviduct and alimentary tract of chickens [3, 4, 12] with adverse effects on egg quality, egg production and marked depression of growth especially in the laying birds [7]. The most notable signs of the disease are those which affect the respiratory tract, hence the term 'infectious bronchitis. These signs include: rales, gasping and sneezing, sometimes accompanied by lacrimation and facial swelling [18]. Infectious bronchitis virus is present in respiratory discharges, faeces and on contaminated eggshells and can survive for a considerable time in faeces and is suspected 
to represent a continuing source of re-infection in the recovery phase of the disease [14]. This virus is transmitted by air droplets, ingestion of contaminated feed and water, and contact with infected chickens. Also, it can be spread through contaminated equipment and clothing of caretakers [5]. For surveillance purposes, an antibody-detecting enzyme-linked immunosorbent assay (ELISA) is the most appropriate test which will detect seroconversion to IBV regardless of the type or origin of the virus [14].

Poultry coronaviruses are antigenically and phylogenetically related [6]. Thus, avian coronavirus from one species has been shown to replicate in other avian species without observation of clinical signs in most instances [13, 15]. Chickens are the main natural hosts of IBV [5]. Although other species such as pheasants, geese, ducks, quails and pigeons have been indicated to play a role in the spread of IBV strains worldwide, to date, the virus only tends to cause disease in chickens $[8,11,14]$. Despite the availability of effective vaccines and efforts to control IB disease by routine use of live and inactivated vaccines in commercial poultry production, IBV being a single stranded RNA virus, has a high propensity to change by both spontaneous mutation and genetic recombination [5]. This tendency continues to cause poor health, high production loss and welfare concerns through recurrent outbreaks due to the emergence of variants especially in the areas of intensive poultry farming $[5,23]$.

In Nigeria, although the southwest region plays a leading role in poultry production [1], there is limited information on infectious bronchitis disease in the region. Most of these studies were on chickens from commercial and backyard farms $[10,21]$. Thus, this study was designed to investigate the presence of IBV antibodies in captured free-living pigeons, intensively reared Japanese quails and free-range indigenous chickens in Oyo and Osun states, in southwest Nigeria.

\section{MATERIALS AND METHODS}

\section{Sample animals}

A total of 184 unvaccinated apparently healthy birds were used in this cross sectional study. The birds comprised of 61 (33 males and 28 females) pigeons from a bird market in Oyo state, 63 (60 females and 3 males) Japanese quails from three flocks in Osun state and 60 (44 females and 16 males) indigenous chickens from five rural areas in Oyo state. While the ages of the pigeons were deemed to be over 6 months by the traders, the quails and indigenous chickens were estimated to be about 12 months old.

\section{Sample collection}

About $2 \mathrm{ml}$ of blood was aseptically collected from the brachial vein of each bird. The blood was allowed to clot at room temperature while sera were separated and stored at $-20^{\circ} \mathrm{C}$ until tested.

\section{Detection of IBV antibodies}

The sera were screened using a commercially available Green Spring ${ }^{\circledast}$ indirect enzyme-linked immunosorbent assay (ELISA) kit (Shenzhen Lvshiyuan Biotechnology, China) that detects infectious bronchitis virus IgG antibodies. The ELISA procedure was carried out according to the manufacturer's protocol and the optical density (OD) was read using an ELISA reader at double wavelengths of 450 and $630 \mathrm{~nm}$. For each sample, the result was expressed as sample/positive $(\mathrm{S} / \mathrm{P})$ value using:

$$
\mathrm{S} / \mathrm{P}=\frac{\mathrm{OD} \text { sample }-\mathrm{OD} \text { negative control }}{\text { OD positive control }- \text { OD negative control }}
$$

Samples that presented $\mathrm{S} / \mathrm{P} \geq 0.2$ and less than 0.2 were considered positive and negative, respectively.

\section{Statistical analysis}

Results obtained were analyzed using the statistical package GraphPad Prism version 5.01 (San Diego, USA). Data were subjected to One-way ANOVA and subsequently to Tukey's post test to perform multiple comparisons in order to assess the statistical significance of differences between all possible pairs of groups. The level of statistical significance was $\mathrm{P}<0.05$.

\section{RESULTS}

Out of the 184 birds sampled, 3.3\% (2/61), $95.0 \%$ $(57 / 60)$ and $6.3 \%(4 / 63)$ were positive for IBV antibodies in pigeons, indigenous chickens and Japanese quails respectively (Table 1). 
TABLE 1. Seroprevalence of infectious bronchitis virus in species of birds

\begin{tabular}{ccc}
\hline Species & $\begin{array}{c}\text { Number } \\
\text { sampled }\end{array}$ & $\begin{array}{c}\text { Positive } \\
{[\%]}\end{array}$ \\
\hline Female & PIGEONS & $0(0.0)$ \\
Male & 28 & $2(6.1)$ \\
& 33 & $\mathbf{2 ( 3 . 3 )}$ \\
\hline Female & $\mathbf{6 1}$ & $41(93.2)$ \\
Male & 44 & $16(100.0)$ \\
& 16 & $\mathbf{5 7}(\mathbf{9 5 . 0})$ \\
\hline Female & $\mathbf{6 0}$ & $4(6.7)$ \\
Male & QUAILS & $0(0.0)$ \\
& 60 & $\mathbf{4 ( 6 . 3 )}$ \\
\hline
\end{tabular}

The mean $S / P$ value $(0.63 \pm 0.3)$ was highest in the indigenous chickens, followed by Japanese quails $(0.45 \pm 0.4)$ and pigeons $(0.20 \pm 0.0)$. The overall seroprevalence of IBV in all species of birds in this study was $34.2 \%$. The seroprevalence of IBV based on sex of the species of birds varied but was not statistically significant $(\mathrm{P}>0.05)$.

\section{DISCUSSION}

Infectious bronchitis is a major viral disease of birds that cause significant economic loss in poultry production but whose impact on African poultry is still poorly known $[9,19)$. This study investigated the presence of infectious bronchitis antibodies in captured free-living pigeons, free range indigenous chickens and intensively reared Japanese quails in Oyo and Osun states, in southwest Nigeria. Additionally, IBV antibody prevalence of 3.3\%, $95.0 \%$ and $6.3 \%$ were obtained respectively for pigeons, indigenous chickens and Japanese quails, an indication that the infection was more prevalent in indigenous chickens than in quails and pigeons. This finding is similar to previous reports of high levels of circulation of IBV in chickens in some West African countries with seroprevalence rates above $70 \%$ [10, $19,20]$ and supports the possible carrier status of indigenous chickens in the transmission of the virus particularly to commercial poultry [2] and perhaps, to other birds. Furthermore, since these birds were not vaccinated against IB and were apparently healthy, the detection of antibodies is an indication that they had been naturally exposed to the virus. In addition, it has been reported that IB virus replicates in the gut for longer periods than in the respiratory tract and the infection of enteric tissues usually does not manifest itself clinically, but persists for long periods and results in faecal virus excretion [17]. Hence, these birds could serve as reservoirs shedding the virus into the environment, thus playing a key role in the epidemiology of the disease.

Avian coronavirus from one species has been shown to replicate in other avian species without observation of clinical signs in most instances $[13,15]$. Consequently, the detection of IBV antibodies in pigeons and Japanese quails in this study indicate seroconversion following natural exposure to the virus. Infectious bronchitis virus can survive for a considerable time in faeces and is suspected to represent a continuing source of re-infection of the disease (14], hence, the detection of IBV antibodies in pigeons and Japanese quails in this study may be due to contact with contaminated feed and water, and may be further supported by the observation of pigeons around commercial poultry houses in southwestern Nigeria scavenging for feed and housing of quails in close proximity to chickens. Similarly, the detected antibodies could be as a result of contact with contaminated equipment and clothing of farm handlers [5] which have also been implicated in the spread of IBV. This fact is further supported by studies elsewhere that revealed the detection of IBV in ducks, turkeys, pigeons, quails and geese and their possible role in the spread of IBV $[8,11,22]$.

\section{CONCLUSIONS}

The findings of this study revealed that infectious bronchitis virus presently circulate in pigeons, indigenous chickens and Japanese quails in Oyo and Osun states, in Southwest Nigeria; indicating that these species of birds, mainly indigenous chickens, serve as reservoirs for infectious bronchitis virus or related viruses. Thus, this finding underscores the importance of the routine surveillance for IBV in different avian species. There is a need for further studies to determine the genotype and serotype of IBV strains circulating in southwestern Nigeria. 


\section{REFERENCES}

1. Adene, D. F., Oguntade, A.E., 2006: The structure and importance of the commercial and rural based poultry industry in Nigeria. Poultry Sector Country Review, FAO animal production and health division, FAO, Rome, 1-70.

2. Adene, D. F., Oyejide, A., Owoade, A. A., 1985: Studies on the possible roles of naturally infected Nigerian local chickens and vaccine virus in the epidemiology of infectious bursal disease. Rev. Elevage Med. Vet. Pays Trop., 38, 122-126.

3. Awad, F., Chhabra, R., Baylis, M., Ganapathy, K., 2014: an overview of infectious bronchitis virus in chickens. World's Poultry Science Journal, 70, 375-383.

4. Benyeda, Z., Mató, T., Süveges, T., Szabó, É., Kardi, V., Abonyi-Tóth, et al., 2009: Comparison of the pathogenicity of QX-like, M41 and 793/B infectious bronchitis strains from different pathological conditions. Avian Pathol., 38, 449-456.

5. Cavanagh, D., Gelb, J., 2008: Infectious bronchitis. In Saif, Y.M., Fadly, A.M., Glisson, J. R., Mcdougald, L. R., Nolan, L. K., Swayne, D.E. (Eds): Diseases of Poultry. Ames, Iowa Blackwell, USA, 117-133.

6. Cavanagh, D., Mawditt, K., Welchman, D., De, B., Britton, P., Gough, R.E., 2002: Coronaviruses from pheasants (Phasianus colchicus) are genetically closely related to coronaviruses of domestic fowl (infectious bronchitis virus) and turkeys. Avian Pathol., 31, 81-93.

7. Cavanagh, D., Naqi, S.A., 2003: Infectious bronchitis. In Diseases of Poultry, 11th edn., Ames Iowa, Iowa state University Press, 101-119.

8. De Wit, J.J., Cook, J.K.A., Van Der Heijden, H.M.J.F., 2011: Infectious bronchitis virus variants: A review of the history, current situation and control measures. Avian Pathol., 40, 223-235.

9. Ducatez, M. F., Martin, A. M., Owoade, A. A., Olatoye, I. O., Alkali, B.R., Maikano, I., et al., 2009: Characterization of a new genotype and serotype of infectious bronchitis virus in Western Africa. J. Gen. Virol., 90, 2679-2685.

10. Emikpe, B. O., Ohore, O.G., Olujonwo, M., Akpavie, S. O., 2010: Prevalence of antibodies to infectious bronchitis virus (IBV) in chickens in southwest Nigeria. Afr. J. Microbiol. Res., 4, 92-95.

11. Felippe, P.A., Da Silva, L.H., Santos, M.M., Spilki, F.R., Arns, C. W., 2010: Genetic diversity of avian infectious bronchitis virus isolated from domestic chicken flocks and coronaviruses from feral pigeons in Brazil between 2003 and 2009. Avian Dis., 54, 1191-1196.
12. Ganapathy, K., Wilkins, M., Forrester, A., Lemiere, S., Cserep, T., Mcmullin, P., Jones, R.C., 2012: QX-like infectious bronchitis virus isolated from cases of proventriculitis in commercial broilers in England. Vet Rec., 171, 597.

13. Guy, J. S., 2000: Turkey coronavirus is more closely related to avian infectious bronchitis virus than to mammalian coronaviruses. Avian Pathol., 29, 2017-212.

14. Ignjatovic, J., Sapats, S., 2000: Avian infectious bronchitis virus. Rev. Sci. Tech. Off. Int. Epiz., 19, 49-508.

15. Ismail, M. M., Tang, A. Y., Saif, Y. M., 2003: Pathogenicity of turkey coronavirus in turkeys and chickens. Avian Dis., 47, $515-522$.

16. Jackwood, M. W., Hall, D., Handel, A., 2012: Molecular evolution and emergence of avian gammacoronaviruses. Infect. Genet. Evol., 12, 1305-1311.

17. Jones, R. C., 2010: Viral respiratory diseases (ILT, aMPV infections, IB): are they ever under control? British Poult. Sci., $51,1-11$.

18. Jordan, F.T.W., Pattison, M., 1999: Poultry Diseases. 4th edn., WB Saunders Co. Ltd., 17-186.

19. Kouakou, A. V., Kouakou, V., Kouakou, C., Godji, P., Kouassi, A.L., Krou, H.A., et al., 2015: Prevalence of Newcastle disease virus and infectious bronchitis virus in avian influenza negative birds from live bird markets and backyard and commercial farms in Ivory Coast. Res. Vet. Sci., 102, 83-88.

20. Ntirandekura, J. B., 2011: Séroprévalence de la bronchite infectieuse en aviculture traditionnelle au Sénégal (Mémoire de diplôme de Master). En santé publique vétérinaire, présenté et soutenu publiquement le 30 Novembre 2011 à l'Ecole InterEtats des Sciences et Médecine Vétérinaires de Dakar (Sénégal) à $16 \mathrm{~h}, 41 \mathrm{pp}$.

21. Oyejide, A., Demangam, V.L., Akinyemi, J. O., 1988: Serological survey of antibodies to infectious bronchitis in commercial and indigenous Nigerian chickens using ELISA. Bull. Anim. Health Prod. Afr., 3, 259-262.

22. Sabarinath, A., Sabarinath, G. P., Tiwari, K.P., Kumthekar, S.M., Thomas, D., Sharma, R.N., 2011: Seroprevalence of infectious bronchitis virus in birds of Grenada. Int. J. Poult. Sci., 10, 266-268.

23. Zanella, A., Lavazza, A., Marchi, R., Martin, A. M., Paganelli, F., 2003: Avian infectious bronchitis: characterization of new isolates from Italy. Avian Dis., 47, 180-185.

\section{Received October 3, 2016}

Accepted December 18, 2016 